\title{
Hypoxia-Induced Lipid Peroxidation in the Brain During Postnatal Ontogenesis
}

\author{
H. RAUCHOVÁ ${ }^{1,2}$, M. VOKURKOVÁ ${ }^{1,2}$, J. KOUDELOVÁ ${ }^{3}$ \\ ${ }^{1}$ Centre for Cardiovascular Research, Prague, Czech Republic, ${ }^{2}$ Institute of Physiology, Academy of \\ Sciences of the Czech Republic, Prague, Czech Republic, ${ }^{3}$ Institute of Physiology, First Faculty of \\ Medicine, Charles University, Prague, Czech Republic
}

Received April 13, 2012

Accepted May 25, 2012

\section{Summary}

Reactive oxygen species (ROS) are common products of the physiological metabolic reactions, which are associated with cell signaling and with the pathogenesis of various nervous disorders. The brain tissue has the high rate of oxidative metabolic activity, high concentration of polyunsaturated fatty acids in membrane lipids, presence of iron ions and low capacity of antioxidant enzymes, which makes the brain very susceptible to ROS action and lipid peroxidation formation. Membranes of brain cortex show a higher production of thiobarbituric acid-reactive substances (TBARS) in prooxidant system (ADP.Fe ${ }^{3+} / \mathrm{NADPH}$ ) than membranes from the heart or kidney. Lipid peroxidation influences numerous cellular functions through membrane-bound receptors or enzymes. The rate of brain cortex $\mathrm{Na}^{+}, \mathrm{K}^{+}$-ATPase inhibition correlates well with the increase of TBARS or conjugated dienes and with changes of membrane fluidity. The experimental model of short-term hypoxia (simulating an altitude of $9000 \mathrm{~m}$ for $30 \mathrm{~min}$ ) shows remarkable increase in TBARS in four different parts of the rat brain (cortex, subcortical structures, cerebellum and medulla oblongata) during the postnatal development of Wistar rat of both sexes. Young rats and males are more sensitive to oxygen changes than adult rats and females, respectively. Under normoxia or hypobaric hypoxia both ontogenetic aspects and sex differences play a major role in establishing the activity of erythrocyte catalase, which is an important part of the antioxidant defense of the organism. Rats pretreated with L-carnitine (and its derivatives) have lower TBARS levels after the exposure to hypobaric hypoxia. The protective effect of L-carnitine is comparable with the effect of tocopherol, well-known reactive species scavenger. Moreover, the plasma lactate increases after a short-term hypobaric hypoxia
\end{abstract}

and decreases in L-carnitine pretreated rats. Acute hypobaric hypoxia and/or L-carnitine-pretreatment modify serum but not brain lactate dehydrogenase activity. The obtained data seem to be important because the variations in oxygen tension represent specific signals of regulating the activity of many specific systems in the organism.

\section{Key words}

Hypobaric hypoxia - Reactive oxygen species (ROS) • Polyunsaturated fatty acids - $\mathrm{Na}^{+}, \mathrm{K}^{+}$-ATPase - Catalase • L-carnitine

\section{Corresponding author}

H. Rauchová, Institute of Physiology, Academy of Sciences of the Czech Republic, Vídeňská 1083, 14220 Prague 4, Czech Republic. Fax: ++420 241062 488. E-mail: rauchova@biomed.cas.cz

\section{Brain energy metabolism}

The brain belongs to organs with the very active energy metabolism. At rest it is responsible for $20 \%$ of the total oxygen consumption in the body, although it represents only a small part of body weight. The brain needs the constant continual delivery of oxygen and glucose for the function of central nervous system. Its total energy reserves (including glycogen) are sufficient to maintain normal energy demands for about 80 seconds if the supply of substrates is completely interrupted (Ames 2000). The free energy of ATP is utilized for ion transport, synthetic work (synthesis of neurotransmitters) and a permanent rebuilding of various structural units. 
Most of ATP in the brain is produced from glucose by oxidative phosphorylation in mitochondria and only $1-5 \%$ is produced by glycolysis in cytosol (Erecińska and Silver 1989).

In the brain of suckling mammals ketone bodies (generated in the liver) appear to be at least as important as glucose as a source of metabolic fuel, because all developing mammals are fed with milk with high-fat content (Hawkins et al. 1971). The immature brain is able to consume, incorporate and metabolize a large number of organic metabolites such as lactic acid, acetoacetate, $\beta$-hydroxybutyrate, free fatty acids or amino acids if they are available in reasonable concentrations in blood and if there are appropriate enzymes for their degradation (Drahota et al. 1965, Hawkins et al. 1971, Vannucci and Vannucci 2000). On the other hand, the adult brain can also obtain its energy from ketone bodies when glucose is less available, e.g. during hypoglycemia, fasting or strenuous exercise (Hasselbalch et al. 1994, Vannucci and Vannucci 2000). The concentration of ATP in the brain is maintained under steady-state conditions but the ATP production can vary between cell types and/or brain regions (Erecińska and Silver 1989).

\section{Reactive oxygen species formation}

Common products of normal metabolism are reactive (chemically unstable) oxygen species (ROS), which include $\mathrm{O}_{2}$-derived free radicals such as superoxide anion $\left(\mathrm{O}^{2 \cdot-}\right)$, hydroxyl $\left(\mathrm{HO}^{\circ}\right)$, peroxyl $\left(\mathrm{RO}_{2}{ }^{\circ}\right)$ and alkoxyl $\left(\mathrm{RO}^{\circ}\right)$ radicals, as well as $\mathrm{O}_{2}$-derived non-radical species as hydrogen peroxide $\left(\mathrm{H}_{2} \mathrm{O}_{2}\right)$ or singlet oxygen $\left({ }^{1} \mathrm{O}_{2}\right)$ (Naquie et al. 1986). ROS react quickly with the nearest stable molecule to capture the electron. The injured molecule loses its electron becoming a radical species itself. The most toxic reactive radical is $\mathrm{HO}^{\circ}$ with half-life of $10^{-9}$ seconds, which can interact only in the place of its formation. The major intracellular producers of ROS are mitochondria (Lenaz 2001, Turrens 2003, Bernacchia et al. 2004, Genova et al. 2004, Adam-Vizi 2005). In their classical study Chance et al. (1979) estimated that about $1-2 \%$ of the oxygen is leaked from respiratory chain and forms $\mathrm{O}^{2 \cdot-}$. Later Fridowich (2004) reviewed this value because previous estimates were derived from rat liver and rat and pigeon heart mitochondria inhibited by cyanide but under normal conditions the fractional univalent reduction of oxygen in the respiratory chain is only $0.1 \%$. On the other hand, Nohl et al. (2003, 2004, 2005) showed arguments against mitochondrial ROS formation in the living cells based on the fact that bioenergetic alterations may result from the mechanical removal of mitochondria from their natural environment and from the general use of inappropriate methods. The question how much $\mathrm{O}^{2 \cdot-}$ mitochondria produce in vivo is still open (Kudin et al. 2004, 2008, Murphy 2009, Brown and Borutaite 2012).

The crucial role in mitochondrial ROS metabolism and oxidative stress response plays a protein p66 ${ }^{\text {Shc }}$ (Migliaccio et al. 1999, Nemoto et al. 2006, Orsini et al. 2006), which is involved in ROS production leading to mitochondrial damage and in aging dysfunction under oxidative stress conditions (Trinie et al. 2009, Ray et al. 2012). Mitochondrial origin of cellular ROS is not exclusive. Besides the mitochondrial respiratory chain there are other sources of ROS formation, e.g. flavincontaining monoamine oxidase located on the mitochondrial outer membrane, cytosolic xanthine oxidase or aldehyde oxidase or microsomal NADH cytochrome $b_{5}$ reductase and NADPH-dependent cytochrome $\mathrm{P}-450$ reductase.

Under physiological conditions ROS production occurs continuously and ROS are necessary to the proper physiological functioning of the body. ROS operate as messengers in intracellular signaling and modulation of cell function including apoptotic process (Dröge 2002, Valko et al. 2007, Leloup et al. 2011, Ray et al. 2012). However, when ROS production is in excess to the capacity of cellular antioxidant systems, oxidative stress occurs. Oxidative stress damages cellular components, including DNA, proteins and lipids. Nucleic acid oxidation can result in strand breakage, nucleic acidprotein cross linking and nucleic base modifications, which can lead to the disruption of transcription, translation or DNA replication (Aust and Eveleigh 1999, Blair 2008, Winczura et al. 2012). Protein oxidation leads to their conformation modifications, possible denaturation, aggregation or precipitation (Sayre et al. 1992, Smith et al. 1992, Winczura et al. 2012). Oxidative damages have the crucial role in many neurological disorders, neurodegenerative diseases and injuries of central nervous system (Adibhatla and Hatcher 2010).

\section{Membrane unsaturated fatty acids and lipid peroxidation in the brain}

The brain contains a high concentration of polyunsaturated fatty acids in membrane lipids, which are suitable targets for free radical attack (Tappel 1973, Reed 
2011). In addition, the brain has low levels of antioxidant enzymes, such as catalase and glutathione peroxidase as compared to other organs (Shohami et al. 1997, Halliwell 2001).

To evaluate the maximum capacity of biological membranes to react with oxygen radicals we measured lipid peroxide formation using in vitro membrane preparations from rat cerebral cortex, heart and kidney where all cytosolic antioxidant defense systems were eliminated. We confirmed the highest quantity of thiobarbituric acid-reactive substances (TBARS) in cerebral cortex in comparison with heart and kidney membranes in both induced lipid peroxidation systems $\left(60\right.$ min at $\left.37^{\circ} \mathrm{C}\right)-$ enzymatic, ADP. $\mathrm{Fe}^{3+} / \mathrm{NADPH}$ and non-enzymatic, ADP. $\mathrm{Fe}^{2+} /$ ascorbate (Rauchová et al. 1993). Higher production of TBARS in cerebral cortex membranes (Fig. 1) was the result of higher content of lipids, which correlated well with the estimated content of lipid phosphorus. Similarly, Piergiacomi et al. (2001) observed higher values of lipid peroxidation measured by chemiluminiscence in mitochondria and microsomes obtained from rat brain in comparison with mitochondria and microsomes obtained from rat kidney in peroxidation-induced system in vitro $\left(120 \mathrm{~min}\right.$ at $37^{\circ} \mathrm{C}$ in the presence of ADP. $\mathrm{Fe}^{2+}$ /ascorbate). According to their experiments, the most sensitive fatty acid for peroxidation was docosahexaenoic acid (C22:6 n3) in brain mitochondria.

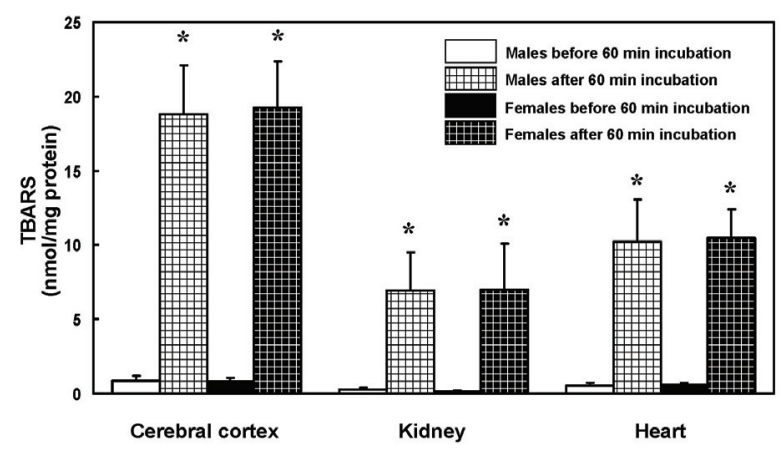

Fig. 1. Lipid peroxidation expressed as levels of TBARS in isolated membranes from cerebral cortex, kidney and heart of 21-day-old Wistar rats. Isolated membranes $(0.5 \mathrm{mg}$ protein) were incubated $60 \mathrm{~min}$ in the presence of $150 \mathrm{mmol} / \mathrm{l} \mathrm{KCl}$, $20 \mathrm{mmol} / \mathrm{l}$ Tris- $\mathrm{HCl}$ buffer $(\mathrm{pH} \mathrm{7.4}), 0.05 \mathrm{mmol} / \mathrm{l} \mathrm{FeCl}, 3 \mathrm{mmol} / \mathrm{l}$ ADP and $0.225 \mathrm{mmol} / \mathrm{I} \mathrm{NADPH}$. The results are given as the means \pm S.D. Significantly different: ${ }^{*} p \leq 0.001$ vs. controls before incubation.

Specific parts of the brain (e.g. substantia nigra) contain high levels of transition metal, such as iron (Drayer et al. 1986, Snyder and Connor 2009). Iron accumulation occurs in a number of neurodegenerative disorders of the central nervous system such as Parkinson's, Alzheimer's and Huntington's diseases, Friedreich's ataxia or amyotrophic lateral sclerosis (Nuñez et al. 2012). Iron can be subsequently converted via the Fenton reaction and Haber-Weiss reaction to the extremely toxic hydroxyl radical (Halliwell and Gutteridge 1984, Winterbourn 1995). Thereafter these free radicals may elicit cellular damage, lipid peroxidation and eventually cytotoxic processes such as apoptosis or necrosis leading to cellular destruction (Gutteridge 1994).

\section{Lipid peroxidation}

Above mentioned factors (the high rate of oxidative metabolic activity, high concentration of polyunsaturated fatty acids in membrane lipids, presence of iron ions and low capacity of antioxidant enzymes) make the brain very susceptible to lipid peroxidation involving the interaction of oxygen-derived free radicals with polyunsaturated fatty acids (Reed 2011). Double bonds of polyunsaturated fatty acids in biological membranes are easily attacked by free radicals, they undergo degradation by a chain reactions and form lipid hydroperoxides. This complex process yields a mixture of epoxy-fatty acids, alkanes, alkenes, alkanals, alkenals, 4-hydroxyalkenals, and aldehydes including malondialdehyde (MDA), which represents about $70 \%$ of the total aldehydes produced during the membrane lipid peroxidation (Esterbauer et al. 1991). One of the oldest, simplest and most widely used methods is the determination of MDA with thiobarbituric acid (Ohkawa et al. 1979, Janero 1990, Esterbauer et al. 1991, Duurfinová et al. 2007, Catalá 2009, Guéraud et al. 2010). However, thiobarbituric acid reacts with several substances that are not related to lipid peroxidation. This may contribute to the overall absorbance, which is not corresponding to the concentration of MDA in vivo but rather to a range of products appropriately termed TBARS. Thiobarbituric assay is often criticized because of low specificity for MDA (Esterbauer 1996, Liu et al. 1997, Dalle-Donne et al. 2006, Lykkesfeldt 2007). Nevertheless, the assay is still frequently used at present time (Seminotti et al. 2011, Weis et al. 2011, Sumathi et al. 2012). To detect and measure biologically relevant lipid peroxidation products many other methods have been developed (Kohen and Nyska 2002, Soh 2006, Wardman 2007, Yin 2008, Vladimirov and Proskurnina 2009, Spickett et al. 2010).

Physiological functions of cell membranes change because lipid peroxidation modifies properties of 
membrane bilayer such as membrane potential, fluidity or permeability to different substances. Consecutively the properties of membrane receptors or membrane-bound enzymes could be altered. For our studies we chose rat cerebral cortex $\mathrm{Na}^{+}, \mathrm{K}^{+}$-ATPase. Membrane-bound $\mathrm{Na}^{+}, \mathrm{K}^{+}$ATPase (EC 3.6.1.9.) plays an essential role in cellular ion homeostasis because it is responsible for generation of the membrane potential through the active transport of sodium and potassium ions (Kaplan 1985, 2002, Lingrel and Kuntzweiler 1994). In the brain this enzyme (moving 3 $\mathrm{Na}^{+}$from inside to outside against $2 \mathrm{~K}^{+}$in the opposite direction with a hydrolysis of 1 ATP molecule) is necessary to maintain neural excitability and cellular volume control. We evaluated the time course of its inactivation after the induction of lipid peroxidation by ADP. $\mathrm{Fe}^{2+} /$ ascorbate prooxidant system (Rauchová et al. 1999). Our data indicated that membrane fluidity changes (evaluated by steady-state anisotropy measuring using DPH and TMA-DPH probes) participate in $\mathrm{Na}^{+}, \mathrm{K}^{+}$-ATPase inhibition during the initial period of lipid peroxidation process, whereas during the following period the enzyme changes inversely correlates with levels of TBARS and conjugated dienes. The influence of lipid peroxidation on $\mathrm{Na}^{+}, \mathrm{K}^{+}$-ATPase is known for 40 years but the different aspects are studied till present time (Sun 1972, Svoboda et al. 1984, Mishra et al. 1989, Jamme et al. 1995, Kaplán et al. 1997, Kurella et al. 1997, Khan et al. 2003, Stefanello et al. 2007, Ribeiro et al. 2011).

\section{Hypoxia}

Hypoxia (insufficient oxygen supply to tissue) was defined by Connett et al. (1990) as oxygen availability not coping with aerobic ATP requirements. This can be paradoxically one of the reasons of increased lipid peroxidation as documented by increased production of indicators of oxidative stress in breath, blood, urine and tissue of laboratory rats or in humans (Askew 2002, Maiti et al. 2006, Behn et al. 2007). During hypoxia less oxygen is available to be completely reduced to water at mitochondrial cytochrome oxidase. Thus, reduced equivalents are accumulated in respiratory chain. The accumulation leads to ROS formation by the autooxidation of mitochondrial complexes with direct reduction of oxygen to superoxide and hydroxyl radical (Kehrer and Lund 1994). Besides mitochondrial respiratory chain other enzymes may contribute to an increased ROS formation under hypoxia, e.g. nitric oxide synthase (Turrens 2003) and xanthine oxidase (Dosek et al. 2007). Hypoxic cells are associated not only with biochemical alterations (Nakanishi et al. 1995, Li and Jackson 2002, Solaini et al. 2010) but also with different morphological changes (Oechmichen and Meissner 2006, Titus et al. 2007, Ježek and Plecitá-Hlavatá 2009). ROS released during hypoxia are key signals that trigger transcriptional regulators such as hypoxia-inducible factor-1 (HIF-1), nuclear factor $\kappa \mathrm{B}(\mathrm{NF}-\kappa \mathrm{B})$, activator protein 1 (AP-1) and some mitogen-activated protein kinases (MAPK) (Semenza 2000, 2012, Li and Jackson 2002, Poyton et al. 2009). The brain is very complicated organ containing metabolically heterogeneous cell populations (Kalous et al. 2001). There are large variations in the vulnerability of different parts of the brain to hypoxia (Ikonomidou et al. 1989, Wang and Michaelis 2010). Moreover, the resistance to oxygen deficiency changes during the ontogenesis (Trojan 1978).

In our experimental model of short-term hypoxia simulating an altitude of $9000 \mathrm{~m}$ (air pressure $=30.7 \mathrm{kPa}$, $\mathrm{pO}_{2}=6.4 \mathrm{kPa}$ ) for $30 \mathrm{~min}$ we followed the changes in TBARS in four different parts of the rat brain: cortex, subcortical structures (including the thalamus, hypothalamus and basal ganglia), cerebellum and medulla oblongata during the postnatal development from 3-dayold till 90-day-old Wistar rats of both sexes. The increase of TBARS was estimated immediately after removing animals from the barometric chamber. We found the higher TBARS increases following acute hypoxia in the immature brain tissue than in the brain of adult rats (35- and 90-day-old). There were no significant changes in 35-day-old rats, whereas in 90-day-old rats we found significant increase of TBARS level only in the phylogenetical youngest brain region, i.e. cortex (Fig. 2).

Combination of different conditions (duration of hypoxia, type of hypoxia, duration of reoxidation) showed also age-dependent results: young rats were more sensitive to any hypoxic damage in comparison with the older ones studied after the end of weaning period (Koudelová and Mourek 1992, Koudelová et al. 1992). Paradoxically, we found that lipid peroxidation in the mature brain was lower as compared with lipid peroxidation in the immature brain in spite of the higher content of polyunsaturated fatty acids in mature brain (Šmídová et al. 1984). This fact could be explained by the lower activities of antioxidant enzymes in immature rats as we showed for erythrocyte catalase (Rauchová et al. 2005). We also found that the male brain tissue was more sensitive to hypoxia-induced lipid peroxidation in comparison with the female one. 

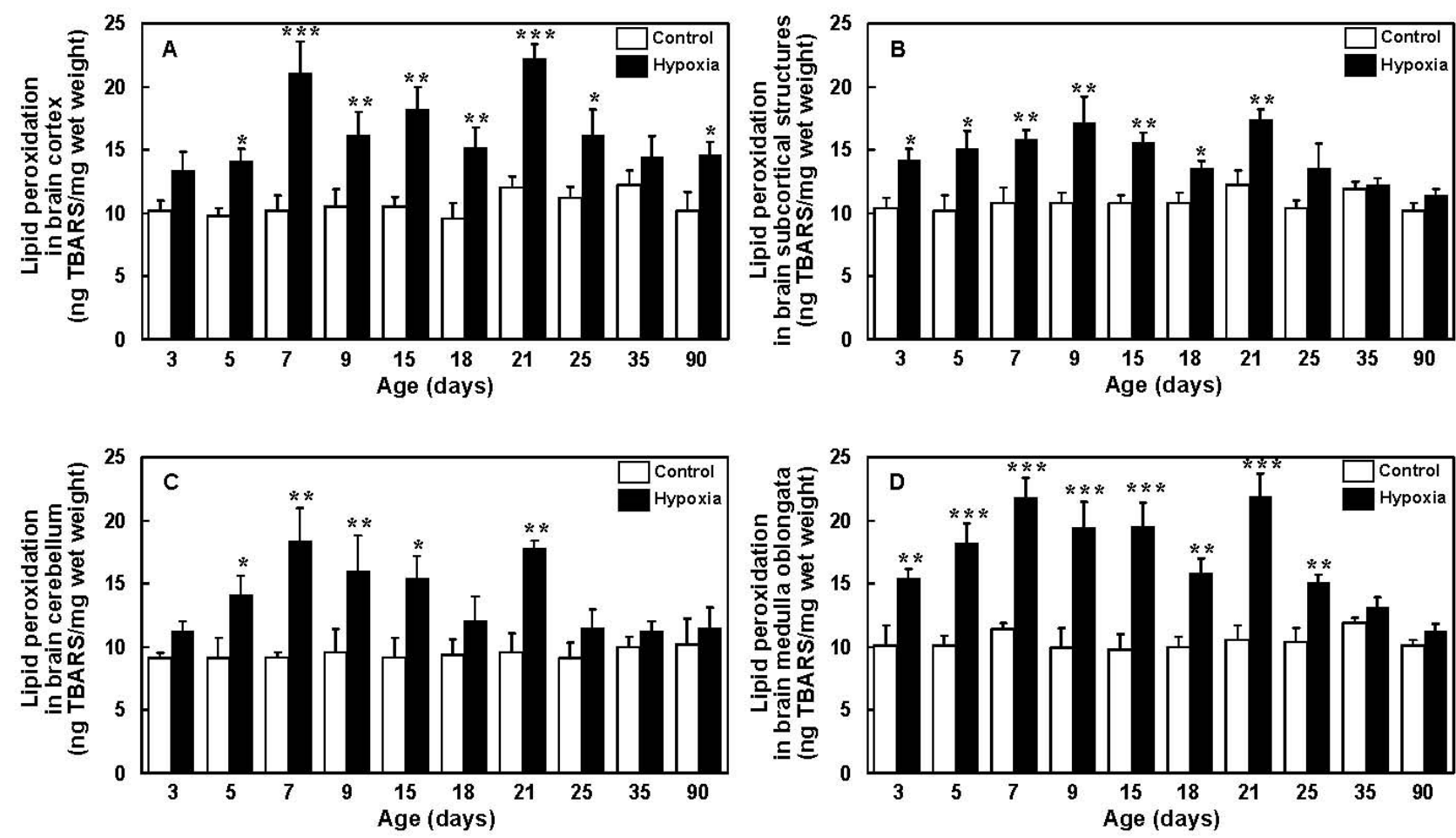

Fig. 2. Lipid peroxidation expressed as levels of TBARS in cerebral cortex (A), subcortical structures (B), cerebellum (C) and medulla oblongata (D) in controls and in Wistar rats of different age after 30 min hypobaric hypoxia. The results are given as the means \pm S.D. Significantly different: ${ }^{*} p \leq 0.05,{ }^{* *} p \leq 0.01$ and ${ }^{* * *} p \leq 0.01$ vs. controls.

Table 1. The effect of hyperoxia on lipid peroxidation expressed as levels of TBARS ( $\mathrm{ng} / \mathrm{mg}$ wet weight) in the different part of the brain in 7-day-old, 21-day-old and adult rats.

\begin{tabular}{lccccccc}
\hline & & \multicolumn{2}{c}{$\begin{array}{c}\text { 7-day-old rats } \\
\mathbf{1 0 0} \%\end{array}$} & \multicolumn{2}{c}{$\begin{array}{c}\text { 21-day-old rats } \\
\mathbf{1 0 0} \%\end{array}$} & \multicolumn{2}{c}{ Adult rats } \\
& Sex & Controls & $\begin{array}{c}\text { Oxygen } \\
\text { Oxygen }\end{array}$ & Controls & Controls & $\begin{array}{c}\mathbf{1 0 0} \% \\
\text { Oxygen }\end{array}$ \\
\hline Cortex & $\mathrm{M}$ & $7.8 \pm 0.5$ & $18.4 \pm 2.0^{* *}$ & $11.3 \pm 0.5$ & $16.4 \pm 0.2^{* *}$ & $9.3 \pm 0.6$ & $11.6 \pm 0.4^{*}$ \\
& $\mathrm{~F}$ & $6.9 \pm 1.1$ & $9.5 \pm 0.2^{* \# \#}$ & $10.8 \pm 0.4$ & $11.1 \pm 0.4^{\# \#}$ & $9.0 \pm 0.4$ & $9.3 \pm 0.8$ \\
Subcortical & $\mathrm{M}$ & $9.1 \pm 0.3$ & $18.1 \pm 1.0^{* *}$ & $11.2 \pm 0.6$ & $14.7 \pm 0.2^{*}$ & $9.3 \pm 0.9$ & $12.7 \pm 0.4^{*}$ \\
structures & $\mathrm{F}$ & $9.5 \pm 0.5$ & $10.5 \pm 0.3^{\# \#}$ & $11.0 \pm 0.4$ & $11.8 \pm 0.3^{\#}$ & $9.6 \pm 0.7$ & $7.7 \pm 0.4^{\#}$ \\
Medulla & $\mathrm{M}$ & $9.3 \pm 0.2$ & $20.4 \pm 0.9^{* *}$ & $13.5 \pm 0.3$ & $18.4 \pm 0.7^{* *}$ & $10.1 \pm 1.0$ & $11.7 \pm 0.9$ \\
oblongata & $\mathrm{F}$ & $13.4 \pm 1.2^{\#}$ & $12.8 \pm 0.9^{\# \#}$ & $11.8 \pm 0.7$ & $11.9 \pm 0.2^{\# \#}$ & $7.8 \pm 0.7^{\#}$ & $5.9 \pm 0.3^{\#}$ \\
Cerebellum & $\mathrm{M}$ & $7.2 \pm 0.2$ & $17.8 \pm 1.2^{* *}$ & $10.4 \pm 0.3$ & $12.3 \pm 0.3^{*}$ & $9.2 \pm 1.0$ & $9.1 \pm 0.6$ \\
& $\mathrm{~F}$ & $7.0 \pm 1.6$ & $7.9 \pm 0.13^{\# \#}$ & $9.6 \pm 0.5$ & $7.1 \pm 0.2^{\# \#}$ & $8.8 \pm 0.4$ & $7.4 \pm 0.8$ \\
\hline
\end{tabular}

Data are presented as means \pm S.E.M. M - males, F - females. Significantly different: $* p \leq 0.05$ and $* * p \leq 0.01$ vs. controls; ${ }^{*} p \leq 0.05$ and ${ }^{\# \#} \mathrm{p} \leq 0.01$ vs. males.

Significantly higher resistance of female brain tissue to induce lipid peroxidation was considerable when rats were exposed to normobaric pure oxygen atmosphere for 30 min (Koudelová and Mourek 1994) as shown in Table 1. A similar model of normobaric $100 \%$ hyperoxia with similar values of lipid peroxidation in brain tissue of adult and aged (30-month-old) rats was reported by Tong et al. (2002) who further demonstrated the attenuation in the DNA binding activity of the AP-1 and NF- $\kappa B$ transcription factors in aged rats. There are important components of stress response signal transduction pathways, which can determine the shifts in cellular commitments to necrotic death, apoptotic death or survival in the brain (Tong et al. 2002). 


\section{Antioxidant defense}

Production of oxygen radicals is under the control by efficient cellular and extracellular defense systems. The defense against free-radical-induced damage includes antioxidant enzymes such as superoxide dismutase (SOD), catalase (CAT) and glutathione peroxidase (GPX). In our experiments we followed erythrocyte CAT (EC 1.11.1.6.) in normoxia and after the exposure to intensive acute hypobaric hypoxia (9000 m for $30 \mathrm{~min}$ ) of Wistar rats. During the development CAT activity increased in both sexes but the rise was usually higher in females. Hypobaric hypoxia increased CAT activity in all studied age groups of both sexes. However, higher CAT activity in females was less affected by hypoxia than its lower activity in males. We concluded that both ontogenetic aspects and sex differences play a major role in establishing the activity of CAT, which is an important part of the antioxidant defense of organism (Rauchová et al. 2005).

A non-enzymatic defense includes water-soluble antioxidants such as glutathione, ascorbic acid, uric acid, bilirubin and lipid-soluble antioxidants such as $\alpha$-tocopherol, $\beta$-carotene, melatonin or lipoic acid. Some of antioxidants are synthetized by the cells (glutathione, uric acid, bilirubin, melatonin) but some vitamins are derived from the diet. Several natural antioxidants, such as flavonoids isolated from plants (green tea polyphenols, red wine anthocyanins or soy isoflavone) have radical scavenging activity (Weisburger 1999, Lionetto et al. 2011). Moreover, there are also endogenous agents with radical scavenging activity, such as pyruvate and carnitine. Nontoxic and freely diffusible pyruvate (abundantly present in mammalian cells) is able to scavenge $\mathrm{H}_{2} \mathrm{O}_{2}$ in different cellular compartments (Desagher et al. 1997, Jagtap et al. 2003, Paquin et al. 2005, Wang et al. 2007). A quaternary ammonium compound L-carnitine (a vital cofactor for the mitochondrial oxidation of fatty acids) belongs to natural agents present in all mammalian tissue. L-carnitine (and its derivatives) possess unique neuroprotective, neuromodulatory and neurotrophic properties and are able to decrease the brain injury following an ischemic attack (Matsuoka and Igisu 1992, Zanelli et al. 2005, Picconi et al. 2006) or after hypoxia-ischemia in newborn rats (Wainwright et al. 2003, 2006, Onem et al. 2006) or to function as free radical scavengers in aging (Rani and
Panneerselvam 2001, 2002, Muthuswamy et al. 2006).

We found that L-carnitine pretreatment (30 min before hypobaric hypoxia exposure) contributed to lowering of brain lipid peroxidation (Koudelová et al. 1994). In our experiments we also compared the protective effect of L-carnitine with that of well-known lipophilic reactive species scavenger, $\alpha$-tocopherol (Chow 1991). Rats pretreated with $\alpha$-tocopherol or L-carnitine had lower TBARS levels after the exposure to hypobaric hypoxia in comparison with untreated rats (Rauchová et al. 2002). Similarly, rats pretreated with phosphocreatine had lower TBARS levels after the exposure to hypobaric hypoxia. As a marker of hypoxia we followed lactate/pyruvate ratio. Lactate/pyruvate ratio was improved to control value only in rats pretreated with L-carnitine or phosphocreatine. We conclude that protective effect of L-carnitine or phosphocreatine was due to their regulation of metabolic reactions during hypobaric hypoxia rather than to their scavenger activity (Rauchová et al. 2002). Similarly, pretreatments with L-carnitine derivatives, acetyl-L-carnitine or propionyl-Lcarnitine (intraperitoneal administration $30 \mathrm{~min}$ before hypobaric hypoxia exposure) prevented TBARS formation in four different parts of brain (Table 2). The decrease of free radical generation, lipid peroxidation and protein oxidation, which resulted in augmenting of the energy status and amelioration of memory impairment induced by 14-day-hypobaric hypoxia, was reported by Barhwal et al. (2009).

The plasma level of lactate increased after a short-term hypobaric hypoxia and significantly decreased in L-carnitine pretreated rats. One of the possibilities, why plasma lactate was decreased by L-carnitine pretreatment, could be the influence on the activity of lactate dehydrogenase (LDH; EC 1.1.1.27.), which catalyzed a mutual conversion between lactate and pyruvate. The hypoxia exposure increased serum LDH activity of 21-day-old rats only. Pretreatment of rats with L-carnitine decreased serum LDH activity in 21- and 90-day-old rats probably due to membrane stabilizing role of L-carnitine (Di Lisa et al. 1985, Arduini et al. 1990). However, we did not find any significant difference of LDH activity in the brain after the exposure to hypobaric hypoxia or L-carnitine pretreatment (Koudelová et al. 2006). Thus, acute hypobaric hypoxia and/or L-carnitine pretreatment modified serum but not brain LDH activity. 
Table 2. The effect of hypoxia on lipid peroxidation expressed as levels of TBARS ( $\mathrm{ng} / \mathrm{mg}$ wet weight) in the different parts of the brain in 21-day-old rats.

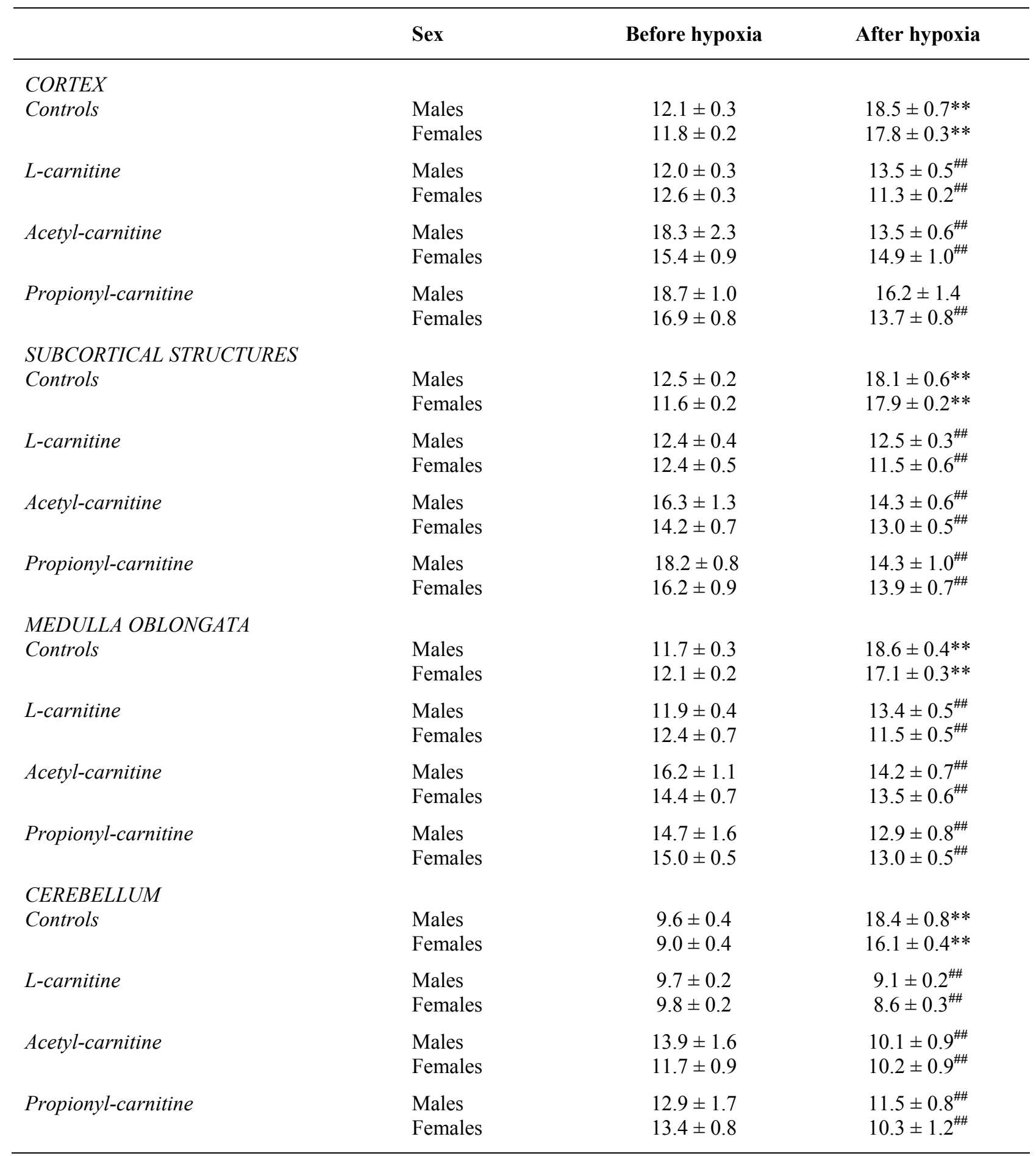

Data are presented as means \pm S.E.M. Significantly different: ${ }^{* *} p \leq 0.01$ vs. the status before hypoxia; ${ }^{\# \#} p \leq 0.01$ vs. controls.

\section{Conclusions}

Our model of hypobaric hypoxia is associated with a paradoxical increase of ROS formation and lipid peroxidation in the brain. The resistance to reactive oxygen species in different parts of brain is dependent on the sex and age of animals. The necessity for fundamental and clinical research aimed to the development of the preventive or therapeutic help using a variety of antioxidant nutritional and pharmacological interventions is increasing. L-carnitine and its derivatives belong to promising natural antioxidants with minimal toxicity and 
excellent tolerability. Their protective effect may be medicated through the regulation of metabolic reactions during hypobaric hypoxia.

\section{Conflict of Interest}

There is no conflict of interest.

\section{Acknowledgements}

This work was supported by the Grant Agency of the Czech Republic (304/12/0259) and the Ministry of Education, Youth and Sports of the Czech Republic (AV0Z 50110509, 1M0510).

\section{References}

ADAM-VIZI V: Production of reactive oxygen species in brain mitochondria: contribution by electron transport chain and non-electron transport chain sources. Antioxid Redox Signal 7: 1140-1149, 2005.

ADIBHATLA RM, HATCHER JF: Lipid oxidation and peroxidation in CNS health and disease: from molecular mechanisms to therapeutic opportunities. Antioxid Redox Signal 12: 125-169, 2010.

AMES A 3RD: CNS energy metabolism as related to function. Brain Res Rev 34: 42-68, 2000.

ARDUINI A, ROSSI M, MANCINELLI G, BELFIGLIO M, SCURTI R, RADATTI G, SHOHET SB: Effect of L-carnitine and acetyl-L-carnitine on the human erythrocyte membrane stability and deformability. Life Sci 47: 2395-2400, 1990.

ASKEW EW: Work at high altitude and oxidative stress: antioxidant nutrients. Toxicology 180: 107-119, 2002.

AUST AE, EVELEIGH JF: Mechanisms of DNA oxidation. Proc Soc Exp Biol Med 222: 246-252, 1999.

BEHN C, ARANEDA OF, LLANOS AJ, CELEDÓN G, GONZÁLEZ G: Hypoxia-related lipid peroxidation: evidences, implications and approaches. Respir Physiol Neurobiol 158: 143-150, 2007.

BERNACCHIA A, BIONDI A, GENOVA ML, LENAZ G, FALASCA A: The various sources of mitochondrial oxygen radicals: a minireview. Toxicol Mech Methods 14: 25-30, 2004.

BLAIR IA: DNA adducts with lipid peroxidation products. J Biol Chem 283: 15545-15549, 2008.

BROWN GC, BORUTAITE V: There is no evidence that mitochondria are the main source of reactive oxygen species in mammalian cells. Mitochondrion 12: 1-4, 2012.

CATALÁ A: Lipid peroxidation of membrane phospholipids generates hydroxy-alkenals and oxidized phospholipids active in physiological and/or pathological conditions. Chem Phys Lipids 157: 1-11, 2009.

CHANCE B, SIES H, BOVERIS A: Hydroperoxide metabolism in mammalian organs. Physiol Rev 59: 527-605, 1979.

CHOW CK: Vitamin E and oxidative stress. Free Radic Biol Med 11: 215-232, 1991.

CONNETT RJ, HONIG CR, GAYESKI TE, BROOKS GA: Defining hypoxia: a systems view of $\mathrm{VO}_{2}$, glycolysis, energetics, and intracellular $\mathrm{PO}_{2}$. J Appl Physiol 68: 833-842, 1990.

DALLE-DONNE I, ROSSI R, COLOMBO R, GIUSTARINI D, MILZANI A: Biomarkers of oxidative damage in human disease. Clin Chem 52: 601-623, 2006.

DESAGHER S, GLOWINSKI J, PRÉMONT J: Pyruvate protects neurons against hydrogen peroxide-induced toxicity. J Neurosci 17: 9060-9067, 1997.

Di LISA F, BOBYLEVA-GUARRIERO V, JOCELYN P, TONINELLO A, SILIPRANDI N: Stabilising action of carnitine on energy linked processes in rat liver mitochondria. Biochem Biophys Res Commun 131: 968-973, 1985.

DOSEK A, OHNO H, ACS Z, TAYLOR AW, RADAK Z: High altitude and oxidative stress. Respir Physiol Neurobiol 158: 128-131, 2007.

DRAHOTA Z, HAHN P, MOUREK J, TROJANOVÁ M: The effect of acetoacetate on oxygen consumption of brain slices from infant and adult rats. Physiol Bohemoslov 14: 134-136, 1965.

DRAYER B, BURGER P, DARWIN R, RIEDERER S, HERFKENS R, JOHNSON GA: MRI of brain iron. $A J R A m J$ Roentgenol 147: 103-110, 1986.

DRÖGE W: Free radicals in the physiological control of cell function. Physiol Rev 82: 47-95, 2002.

ĎURFINOVÁ M, BRECHTLOVÁ M, LÍŠKA B, BAROŠKOVÁ Ž: Comparison of spectrophotometric and HPLC methods for determination of lipid peroxidation products in rat brain tissues. Chem Pap 61: 321-325, 2007.

ERECIŃSKA M, SILVER IA: ATP and brain function. J Cereb Blood Flow Metab 9: 2-19, 1989. 
ESTERBAUER H: Estimation of peroxidative damage. A critical review. Pathol Biol (Paris) 44: 25-28, 1996.

ESTERBAUER H, SCHAUR RJ, ZOLLNER H: Chemistry and biochemistry of 4-hydroxynonenal, malonaldehyde and related aldehydes. Free Radic Biol Med 11: 81-128, 1991.

FRIDOVICH I: Mitochondria: are they the seat of senescence? Aging Cell 3: 13-16, 2004.

GENOVA ML, PICH MM, BERNACCHIA A, BIANCHI C, BIONDI A, BOVINA C, FALASCA AI, FORMIGGINI G, CASTELLI GP, LENAZ G: The mitochondrial production of reactive oxygen species in relation to aging and pathology. Ann N Y Acad Sci 1011: 86-100, 2004.

GUÉRAUD F, ATALAY M, BRESGEN N, CIPAK A, ECKL PM, HUC L, JOUANIN I, SIEMS W, UCHIDA K: Chemistry and biochemistry of lipid peroxidation products. Free Radic Res 44: 1098-1124, 2010.

GUTTERIDGE JM: Hydroxyl radicals, iron, oxidative stress and neurodegeneration. Ann N Y Acad Sci 738: 201-213, 1994.

HALLIWELL B: Role of free radicals in the neurodegenerative diseases: therapeutic implications for antioxidant treatment. Drugs Aging 18: 685-716, 2001.

HALLIWELL B, GUTTERIDGE JM: Oxygen toxicity, oxygen radicals, transition metals and disease. Biochem J 219: 1-14, 1984.

HASSELBALCH SG, KNUDSEN GM, JAKOBSEN J, HAGEMAN LP, HOLM S, PAULSON OB: Brain metabolism during short-term starvation in humans. J Cereb Blood Flow Metab 14: 125-131, 1994.

HAWKINS RA, WILLIAMSON DH, KREBS HA: Ketone-body utilization by adult and suckling rat brain in vivo. Biochem J 122: 13-18, 1971.

IKONOMIDOU C, MOSINGER JL, SALLES KS, LABRUYERE J, OLNEY JW: Sensitivity of the developing rat brain to hypobaric/ischemic damage parallels sensitivity to N-methyl-aspartate neurotoxicity. J Neurosci 9: 2809-2818, 1989.

JAGTAP JC, CHANDELE A, CHOPDE BA, SHASTRY P: Sodium pyruvate protects against $\mathrm{H}_{2} \mathrm{O}_{2}$ mediated apoptosis in human neuroblastoma cell line-SK-N-MC. J Chem Neuroanat 26: 109-118, 2003.

JAMME I, PETIT E, DIVOUX D, GERBI A, MAIXENT JM, NOUVELOT A: Modulation of mouse cerebral $\mathrm{Na}^{+}, \mathrm{K}^{+}-$ ATPase activity by oxygen free radicals. NeuroReport 7: 333-337, 1995.

JANERO DR: Malondialdehyde and thiobarbituric acid-reactivity as diagnostic indices of lipid peroxidation and peroxidative tissue injury. Free Radic Biol Med 9: 515-540, 1990.

JEŽEK P, PLECITÁ-HLAVATÁ L: Mitochondrial reticulum network dynamics in relation to oxidative stress, redox regulation, and hypoxia. Int J Biochem Cell Biol 41: 1790-1804, 2009.

KALOUS M, RAUCHOVÁ H, DRAHOTA Z: Postnatal development of energy metabolism in the rat brain. Physiol Res 50: 315-319, 2001.

KAPLAN JH: Ion movements through the sodium pump. Annu Rev Physiol 47: 535-544, 1985.

KAPLAN JH: Biochemistry of Na, K-ATPase. Annu Rev Biochem 71: 511-535, 2002.

KAPLÁN P, MATEJOVIČOVÁ M, MÉZEŠOVÁ V: Iron-induced inhibition of $\mathrm{Na}^{+}, \mathrm{K}^{+}$-ATPase and $\mathrm{Na}^{+} / \mathrm{Ca}^{2+}$ exchanger in synaptosomes: protection by the pyridoindole stobadine. Neurochem Res 22: 1523-1529, 1997.

KEHRER JP, LUND LG: Cellular reducing equivalents and oxidative stress. Free Radic Biol Med 17: 65-75, 1994.

KHAN FH, SEN T, CHAKRABARTI S: Dopamine oxidation products inhibit $\mathrm{Na}^{+}, \mathrm{K}^{+}$-ATPase activity in crude synaptosomal-mitochondrial fraction from rat brain. Free Radic Res 37: 597-601, 2003.

KOHEN R, NYSKA A: Oxidation of biological systems: oxidative stress phenomena, antioxidants, redox reactions, and methods for their quantification. Toxicol Pathol 30: 620-650, 2002.

KOUDELOVÁ J, MOUREK J: Different degrees of lipid peroxidation in the CNS of young and adult rats exposed to short-term hypobaric hypoxia. Physiol Res 41: 207-212, 1992.

KOUDELOVÁ J, MOUREK J: The lipid peroxidation in various parts of the rat brain: effect of age, hypoxia and hyperoxia. Physiol Res 43: 169-173, 1994.

KOUDELOVÁ J, MOUREK J, TROJAN S: Lipid peroxidation in the developing rat brain. In: Ontogenesis of the Brain, vol.5. S TROJAN, M LANGMEIER (eds), Universitas Carolina, Prague, 1992, pp 89-94.

KOUDELOVÁ J, MOUREK J, DRAHOTA Z, RAUCHOVÁ H: Protective effect of carnitine on lipoperoxide formation in rat brain. Physiol Res 43: 387-389, 1994. 
KOUDELOVÁ J, RAUCHOVÁ H, VOKURKOVÁ M: Activity of lactate dehydrogenase in serum and cerebral cortex of immature and mature rats after hypobaric hypoxia. Neurochem Res 31: 915-919, 2006.

KUDIN AP, BIMPONG-BUTA NY, VIELHABER S, ELGER CE, KUNZ WS: Characterization of superoxideproducing sites in isolated brain mitochondria. J Biol Chem 279: 4127-4135, 2004.

KUDIN AP, MALINSKA D, KUNZ WS: Sites of generation of reactive oxygen species in homogenates of brain tissue determined with the use of respiratory substrates and inhibitors. Biochim Biophys Acta 1777: 689-695, 2008.

KURELLA E, KUKLEY M, TYULINA O, DOBROTA D, MATEJOVIČOVÁ M, MÉZEŠOVÁ V, BOLDYREV A: Kinetic parameters of Na/K-ATPase modified by free radicals in vitro and in vivo. Ann N Y Acad Sci 834: 661665, 1997.

LELOUP C, CASTEILLA L, CARRIÈRE A, GALINIER A, BENANI A, CARNEIRO L, PÉNICAUD L: Balancing mitochondrial redox signaling: a key point in metabolic regulation. Antioxid Redox Signal 14: 519-530, 2011.

LENAZ G: The mitochondrial production of reactive oxygen species: mechanisms and implications in human pathology. IUBMB Life 52: 159-164, 2001.

LI C, JACKSON RM: Reactive species mechanisms of cellular hypoxia-reoxygenation injury. Am J Physiol Cell Physiol 282: C227-C241, 2002.

LINGREL JB, KUNTZWEILER T: $\mathrm{Na}^{+}, \mathrm{K}^{+}$-ATPase. J Biol Chem 269: 19659-19662, 1994.

LIONETTO MG, GIORDANO ME, CALISI A, ERROI E, DE NUCCIO F, SCHETTINO T: Effect of the daily ingestion of a purified anthocyanin extract from grape skin on rat serum antioxidant capacity. Physiol Res 60: 637-645, 2011.

LIU J, YEO HC, DONIGER SJ, AMES BN: Assay of aldehydes from lipid peroxidation: gas chromatography-mass spectrometry compared to thiobarbituric acid. Anal Biochem 245: 161-166, 1997.

LYKKESFELDT J: Malondialdehyde as biomarker of oxidative damage to lipids caused by smoking. Clin Chim Acta 380: 50-58, 2007.

MAITI P, SINGH SB, SHARMA AK, MUTHURAJU S, BANERJEE PK, ILAVAZHAGAN G: Hypobaric hypoxia induces oxidative stress in rat brain. Neurochem Int 49: 709-716, 2006.

MATSUOKA M, IGISU H: Preservation of energy metabolites by carnitine in the mouse brain under ischemia. Brain Res 590: 334-336, 1992.

MIGLIACCIO E, GIORGIO M, MELE S, PELICCI G, REBOLDI P, PANDOLFI PP, LANFRANCONE L, PELICCI PG: The $\mathrm{p}^{\text {shc }}{ }^{\text {sc }}$ adaptor protein controls oxidative stress response and life span in mammals. Nature 402: 309313, 1999.

MISHRA OP, DELIVORIA-PAPADOPOULOS M, CAHILLANE G, WAGERLE LC: Lipid peroxidation as the mechanism of modification of the affinity of the $\mathrm{Na}^{+}, \mathrm{K}^{+}$-ATPase active sites for ATP, $\mathrm{K}^{+}, \mathrm{Na}^{+}$, and strophanthidin in vitro. Neurochem Res 14: 845-851, 1989.

MURPHY MP: How mitochondria produce reactive oxygen species. Biochem J 417: 1-13, 2009.

MUTHUSWAMY AD, VEDAGIRI K, GANESAN M, CHINNAKANNU P: Oxidative stress-mediated macromolecular damage and dwindle in antioxidant status in aged rat brain regions: role of L-carnitine and DL-alpha-lipoic acid. Clin Chim Acta 368: 84-92, 2006.

NAKANISHI K, TAJIMA F, NAKAMURA A, YAGURA S, OOKAWARA T, YAMASHITA H, SUZUKI K, TANIGUCHI N, OHNO H: Effects of hypobaric hypoxia on antioxidant enzymes in rats. $J$ Physiol Lond 489: 869-876, 1995.

NAQUI A, CHANCE B, CADENAS E: Reactive oxygen intermediates in biochemistry. Annu Rev Biochem 55: 137$166,1986$.

NEMOTO S, COMBS CA, FRENCH S, AHN BH, FERGUSSON MM, BALABAN RS, FINKEL T: The mammalian longevity-associated gene product p66shc regulates mitochondrial metabolism. $J$ Biol Chem 281: 1055510560, 2006.

NOHL H, GILLE L, STANIEK K: The mystery of reactive oxygen species derived from cell respiration. Acta Biochim Pol 51: 223-229, 2004.

NOHL H, GILLE L, STANIEK K: Intracellular generation of reactive oxygen species by mitochondria. Biochem Pharmacol 69: 719-723, 2005. 
NOHL H, KOZLOV AV, GILLE L, STANIEK K: Cell respiration and formation of reactive oxygen species: facts and artefacts. Biochem Soc Trans 31: 1308-1311, 2003.

NÚÑEZ MT, URRUTIA P, MENA N, AGUIRRE P, TAPIA V, SALAZAR J: Iron toxicity in neurodegeneration. Biometals: in press 2012.

OECHMICHEN M, MEISSNER C: Cerebral hypoxia and ischemia: the forensic point of view: a review. $J$ Forensic Sci 51: 880-887, 2006.

OHKAWA H, OHISHI N, YAGI K: Assay for lipid peroxides in animal tissues by thiobarbituric acid reaction. Anal Biochem 95: 351-358, 1979.

ONEM G, ARAL E, ENLI Y, OGUZ EO, COSKUN E, AYBEK H, OZCAN AV, SACAR M, BIR LS, BALTALARLI A, BAYCU C: Neuroprotective effects of L-carnitine and vitamin E alone or in combination against ischemiareperfusion injury in rats. J Surg Res 131: 124-130, 2006.

ORSINI F, MORONI M, CONTURSI C, YANO M, PELICCI P, GIORGIO M, MIGLIACCIO E: Regulatory effects of the mitochondrial energetic status on mitochondrial p66Shc. Biol Chem 387: 1405-1410, 2006.

PAQUIN J, AOUFFEN M, DE GRANDPRÉ E, NADEAU R, LANGLOIS D, MATEESCU MA: Neuroprotective and cardioprotective actions of an association of pyruvate, vitamin E and fatty acids. Arzneimittelforschung 55: 359-369, 2005.

PICCONI B, BARONE I, PISANI A, NICOLAI R, BENATTI P, BERNARDI G, CALVANI M, CALABRESI P: Acetyl-L-carnitine protects striatal neurons against in vitro ischemia: the role of endogenous acetylcholine. Neuropharmacology 50: 917-923, 2006.

PIERGIACOMI VA, PALACIOS A, CATALÁ A: Comparative studies on lipid peroxidation of microsomes and mitochondria obtained from different rat tissues: effect of retinyl palmitate. Prostaglandins Leukot Essent Fatty Acids 64: 75-80, 2001.

POYTON RO, CASTELLO PR, BALL KA, WOO DK, PAN N: Mitochondria and hypoxic signaling: a new view. Ann N Y Acad Sci 1177: 48-56, 2009.

RANI PJ, PANNEERSELVAM C: Carnitine as a free radical scavenger in aging. Exp Gerontol 36: 1713-1726, 2001.

RANI PJ, PANNEERSELVAM C: Effect of L-carnitine on brain lipid peroxidation and antioxidant enzymes in old rats. J Gerontol A Biol Sci Med Sci 57: B134-B137, 2002.

RAUCHOVÁ H, KALOUS M, DRAHOTA Z, KOUDELOVÁ J, MOUREK J: Lipid peroxidation in isolated membranes of cerebral cortex, heart and kidney. Physiol Res 42: 323-327, 1993.

RAUCHOVÁ H, DRAHOTA Z, KOUDELOVÁ J: The role of membrane fluidity changes and thiobarbituric acidreactive substances production in the inhibition of cerebral cortex $\mathrm{Na}^{+} / \mathrm{K}^{+}$-ATPase activity. Physiol Res 48: 73$78,1999$.

RAUCHOVÁ H, KOUDELOVÁ J, DRAHOTA Z, MOUREK J: Hypoxia-induced lipid peroxidation in rat brain and protective effect of carnitine and phosphocreatine. Neurochem Res 27: 899-904, 2002.

RAUCHOVÁ H, VOKURKOVÁ M, KOUDELOVÁ J: Developmental changes of erythrocyte catalase activity in rats exposed to acute hypoxia. Physiol Res 54: 527-532, 2005.

RAY PD, HUANG BW, TSUJI Y: Reactive oxygen species (ROS) homeostasis and redox regulation in cellular signaling. Cell Signal 24: 981-990, 2012.

REED TT: Lipid peroxidation and neurodegenerative disease. Free Radic Biol Med 51: 1302-1319, 2011.

RIBEIRO CA, HICKMANN FH, WAJNER M: Neurochemical evidence that 3-methylglutaric acid inhibits synaptic $\mathrm{Na}^{+}, \mathrm{K}^{+}$-ATPase activity probably through oxidative damage in brain cortex of young rats. Int $J$ Dev Neurosci 29: 1-7, 2011.

SAYRE LM, LIN D, YUAN Q, ZHU X, TANG X: Protein adducts generated from products of lipid oxidation: focus on HNE and one. Drug Metab Rev 38: 651-675, 2006.

SEMENZA GL: HIF-1: mediator of physiological and pathophysiological responses to hypoxia. J Appl Physiol 88: 1474-1480, 2000.

SEMENZA GL: Hypoxia-inducible factors in physiology and medicine. Cell 148: 399-408, 2012.

SEMINOTTI B, KNEBEL LA, FERNANDES CG, AMARAL AU, DA ROSA MS, EICHLER P, LEIPNITZ G, WAJNER M: Glycine intrastriatal administration induces lipid and protein oxidative damage and alters the enzymatic antioxidant defenses in rat brain. Life Sci 89: 276-281, 2011. 
SHOHAMI E, BEIT-YANNAI E, HOROWITZ M, KOHEN R: Oxidative stress in closed-head injury: brain antioxidant capacity as an indicator of functional outcome. J Cereb Blood Flow Metab 17: 1007-1019, 1997.

ŠMÍDOVÁ L, BAŠE J, KOUDELOVÁ J, MOUREK J: Developmental fatty acid changes in different parts of the rat brain. Physiol Bohemoslov 33: 427-436, 1984.

SMITH CD, CARNEY JM, TATSUMO T, STADTMAN ER, FLOYD RA, MARKESBERY WR: Protein oxidation in aging brain. Ann N Y Acad Sci 663: 110-119, 1992.

SNYDER AM, CONNOR JR: Iron, the substantia nigra and related neurological disorders. Biochim Biophys Acta 1790: 606-614, 2009.

$\mathrm{SOH}$ N: Recent advances in fluorescent probes for the detection of reactive oxygen species. Anal Bioanal Chem 386: 532-543, 2006.

SOLAINI G, BARACCA A, LENAZ G, SGARBI G: Hypoxia and mitochondrial oxidative metabolism. Biochim Biophys Acta 1797: 1171-1177, 2010.

SPICKETT CM, WISWEDEL I, SIEMS W, ZARKOVIC K, ZARKOVIC N: Advances in methods for the determination of biologically relevant lipid peroxidation products. Free Radic Res 44: 1172-1202, 2010.

STEFANELLO FM, SCHERER EB, KUREK AG, MATTOS CB, WYSE AT: Effect of hypermethioninemia on some parameters of oxidative stress and on $\mathrm{Na}^{+}, \mathrm{K}^{+}$-ATPase activity in hippocampus of rats. Metab Brain Dis 22: 172-182, 2007.

SUMATHI T, SHOBANA C, CHRISTINAL J, ANUSHA C: Protective effect of Bacopa monniera on methyl mercuryinduced oxidative stress in cerebellum of rats. Cell Mol Neurobiol: in press 2012.

SUN AY: The effect of lipoxidation on synaptosomal $\left(\mathrm{Na}^{+}+\mathrm{K}^{+}\right)$-ATPase isolated from the cerebral cortex of squirrel monkey. Biochim Biophys Acta 266: 350-360, 1972.

SVOBODA P, TEISINGER J, VYSKOČIL F: Vanadyl $\left(\mathrm{VO}^{2+}\right)$ induced lipoperoxidation in the brain microsomal fraction is not related to $\mathrm{VO}^{2+}$ inhibition of Na,K-ATPase. Biochem Pharmacol 33: 2493-2497, 1984.

TAPPEL AL: Lipid peroxidation damage to cell components. Fed Proc 32: 1870-1874, 1973.

TITUS AD, SHANKARANARAYANA RAO BS, HARSHA HN, RAMKUMAR K, SRIKUMAR BN, SINGH SB, CHATTARJI S, RAJU TR: Hypobaric hypoxia-induced dendritic atrophy of hippocampal neurons is associated with cognitive impairment in adult rats. Neuroscience 145: 265-278, 2007.

TONG L, TOLIVER-KINSKY T, EDWARDS M, RASSIN DK, WERRBACH-PEREZ K, PEREZ-POLO JR: Attenuated transcriptional responses to oxidative stress in the aged rat brain. $J$ Neurosci Res 70: 318-326, 2002.

TRINEI M, BERNIAKOVICH I, BELTRAMI E, MIGLIACCIO E, FASSINA A, PELICCI P, GIORGIO M: P66Shc signals to age. Aging 1: 503-510, 2009.

TROJAN S: Adaptation of the Central Nervous System to Oxygen Deficiency during Ontogenesis. J CHARVÁT (ed), Acta Univ Carol Med vol. LXXXV, Prague, 1978.

TURRENS JF: Mitochondrial formation of reactive oxygen species. J Physiol Lond 552: 335-344, 2003.

VALKO M, LEIBFRITZ D, MONCOL J, CRONIN MT, MAZUR M, TELSER J: Free radicals and antioxidants in normal physiological functions and human disease. Int J Biochem Cell Biol 39: 44-84, 2007.

VANNUCCI RC, VANNUCCI SJ: Glucose metabolism in the developing brain. Semin Perinatol 24: 107-115, 2000.

VLADIMIROV YA, PROSKURNINA EV: Free radicals and cell chemiluminescence. Biochemistry (Mosc) 74: 1545 $1566,2009$.

WAINWRIGHT MS, KOHLI R, WHITINGTON PF, CHACE DH: Carnitine treatment inhibits increases in cerebral carnitine esters and glutamate detected by mass spectrometry after hypoxia-ischemia in newborn rats. Stroke 37: 524-530, 2006.

WAINWRIGHT MS, MANNIX MK, BROWN J, STUMPF DA: L-carnitine reduces brain injury after hypoxiaischemia in newborn rats. Pediatr Res 54: 688-695, 2003.

WANG X, MICHAELIS EK: Selective neuronal vulnerability to oxidative stress in the brain. Front Aging Neurosci 2: $12,2010$.

WANG X, PEREZ E, LIU R, YAN LJ, MALLET RT, YANG SH: Pyruvate protects mitochondria from oxidative stress in human neuroblastoma SK-N-SH cells. Brain Res 1132: 1-9, 2007. 
WARDMAN P: Fluorescent and luminescent probes for measurement of oxidative and nitrosative species in cells and tissues: progress, pitfalls, and prospects. Free Radic Biol Med 43: 995-1022, 2007.

WEIS SN, SCHUNCK RV, PETTENUZZO LF, KROLOW R, MATTÉ C, MANFREDINI V, DO CARMO R, PERALBA M, VARGAS CR, DALMAZ C, WYSE AT, NETTO CA: Early biochemical effects after unilateral hypoxia-ischemia in the immature rat brain. Int J Dev Neurosci 29: 115-120, 2011.

WEISBURGER JH: Mechanisms of action of antioxidants as exemplified in vegetables, tomatoes and tea. Food Chem Toxicol 37: 943-948, 1999.

WINCZURA A, ZDŻALIK D, TUDEK B: Damage of DNA and proteins by major lipid peroxidation products in genome stability. Free Radic Res 46: 442-459, 2012.

WINTERBOURN CC: Toxicity of iron and hydrogen peroxide: the Fenton reaction. Toxicol Lett 82-83: 969-974, 1995.

YIN H: New techniques to detect oxidative stress markers: mass spectrometry-based methods to detect isoprostanes as the gold standard for oxidative stress in vivo. Biofactors 34: 109-124, 2008.

ZANELLI SA, SOLENSKI NJ, ROSENTHAL RE, FISKUM G: Mechanisms of ischemic neuroprotection by acetyl-Lcarnitine. Ann N Y Acad Sci 1053: 153-161, 2005. 